\title{
Pathological assessments for the presence of hexanucleotide repeat expansions in C9ORF72 in Alzheimer's disease
}

Yvonne S Davidson, Andrew C Robinson, Julie S Snowden and David MA Mann*

\begin{abstract}
Background: We have sought histological evidence, using TDP-43 and p62 immunohistochemistry, for the presence of expansions in C9ORF72 among 200 patients with pathologically confirmed AD.

Results: We noted TDP-43 pathological changes in hippocampus and temporal cortex in 45 (22.5\%) of these patients, but did not detect any cases where p62 positive changes in hippocampus and cerebellum, considered pathognomic for C9ORF72 expansions, were present.

Conclusion: We conclude that expansions in C9ORF72 associated with AD are a rare occurrence, and in those instances in the literature where these have been reported, the presence of AD may in fact be coincidental and unrelated to the expansion.
\end{abstract}

Keywords: Alzheimer's disease, Genetics, C9ORF72

\section{Background}

Frontotemporal Lobar Degeneration (FTLD) is a clinical, pathological and genetically heterogeneous condition. The major clinical syndromes principally involve personality and behavioural change (behavioural variant frontotemporal dementia, or bvFTD) or language alterations of a fluent (semantic dementia) or non-fluent (agrammatic aphasia) nature [1]. All three syndromes can be accompanied by Motor Neurone Disease (MND), though bvFTD and MND is the most common combination. Histologically, about half of cases have tau-based pathology, half have TDP-43-based pathology, and about 5\% have FUS-based pathology [2]. Importantly, around $40 \%$ of cases have a strong family history of similar disease, irrespective of clinical or histological subtype, and associate with variations in three major genes - mutations in tau (MAPT) [3] and progranulin $(G R N)[4,5]$, or a large hexanucleotide (GGGGCC) expansion in C9ORF72 [6-8].

The expansion in C9ORF72 occurs in the first intron or the promoter region of the gene, depending upon the transcript isoform in question, and can number up to as

\footnotetext{
* Correspondence: david.mann@manchester.ac.uk

Clinical and Cognitive Sciences Research Group, Institute of Brain, Behaviour and Mental Health, Faculty of Medical and Human Sciences, University of Manchester, Salford Royal Foundation NHS Trust, Salford M6 8HD, UK
}

many as 1500 repeats [6-8]. The expansion is found in about one in every twelve patients with FTLD or MND, making it the most common genetic causes of both these disorders [6-8]. Pathologically, most cases of FTLD bearing the expansion [6-12], like many non-mutational cases of FTLD [2], show inclusion bodies within neurones (NCI) and glial cells of the cerebral cortex and hippocampus that contain the nuclear transcription factor, TDP-43, and are said bear a TDP-43 histological subtype termed FTLD-TDP type B (according to Mackenzie classification [13]), compatible with a clinical diagnosis of FTD and MND. Others, however, show a TDP-43 histological type characterised by the presence of many short neurites (DN) along with NCI within the outer layers of the cerebral cortex, and are termed FTLD-TDP type A [13]. Nonetheless, irrespective of TDP-43 histological type, all patients with FTLD (and indeed those with MND) reported to bear expansion in C9ORF72 also show a unique pathology within the dentate gyrus granule cells and CA4 pyramidal cells of the hippocampus [9] and granule cells of the cerebellum $[9,10]$ characterised by NCI that are TDP43 negative, but immunoreactive to p62 protein [6-12].

Interestingly, expansions have been reported to occur within patients with other neurodegenerative disorders, particularly Alzheimer's disease (AD) ([14-18] but see [19,20]). 
However, in many of these individuals where an expansion has been reported [14-18], there has been no pathological confirmation of disease histology, and therefore the underlying condition in such cases could still be FTLD, though presenting in an atypical way. Nonetheless, there do still appear to be some cases of clinically relevant and pathologically confirmed AD bearing expansions in C9ORF72 [16,17].

About 25-45\% cases of AD also show (secondary) TDP43 pathological changes within the amygdala, hippocampus, and sometimes also in neocortical regions [21-24], the proportion of 'positive' cases seemingly being dependent upon how extensively the brain is sampled [21] Cases are frequently encountered where TDP-43 pathological changes are confined to the amygdala, and consequently such 'incidental' cases may be considered negative if this region is not examined [21]. However, when the neocortex and hippocampus are also involved, the histological pattern usually resembles that of FTLD-TDP type A $[21,22]$. In those cases of pathologically confirmed AD where expansions are present $[16,17]$ no TDP-43 or p62 immunostaining had apparently been performed. It is therefore possible that cases of AD bearing expansions, like those with FTLD or MND [6-12], should show p62 changes in the hippocampus and cerebellum, as well as a widespread TDP-43 proteinopathy.

Given that p62 changes in the hippocampus and cerebellum might be pathognomic for expansions in C9ORF72 $[9,11]$, we immunostained sections of temporal cortex (with hippocampus) and cerebellum in 200 pathologically confirmed cases of $\mathrm{AD}$ in order to ascertain to what extent an expansion in C9ORF72 might be present in $\mathrm{AD}$, particularly in those cases with (extensive) TDP43 pathology, since it is possible that such cases, in the context of a clinical picture resembling $\mathrm{AD}$, might be ones with undisclosed/unrecognised FTLD.

\section{Methods}

Brain tissues were available in the Manchester Brain Bank from a series of 200 patients with pathologically confirmed AD (96 with early onset AD, 104 with late (ie after 65 years) onset AD. All brains had been obtained with full ethical permission following consent by the next of kin. Paraffin sections were cut (at a thickness of $6 \mu \mathrm{m}$ ) from formalin fixed blocks of temporal cortex (with hippocampus) and cerebellar cortex and immunostained by routine methods, involving pressure cooking for antigen retrieval, for TDP-43 [22], and p62-lck ligand (rabbit polyclonal antibody (B D Biosciences, Oxford, UK) 1:100), employing a standard $A B C$ Elite kit (Vector, Burlingame, CA, USA) with DAB as chromagen [22].

Immunostained sections were assessed for presence of TDP-43 pathological changes within the hippocampus dentate gyrus, the entorhinal cortex/fusiform gyrus and the inferior and middle temporal gyri [22]. P62 pathological changes were sought within the dentate gyrus and CA2/3/4 regions of the hippocampus, and within the granule cell layer of the cerebellum, as described previously by Al-Sarraj et al. [9], and Boxer et al. [10], respectively. Positive cases were defined where either TDP-43 positive, or p62 positive, TDP-43 negative NCI, within either the cerebellum or hippocampus could be clearly seen under low power objective (X20) and the majority of high power fields (x40) contained at least 2 NCI. Negative cases were either completely devoid of TDP-43 or p62 immunostaining, or showed only small amounts of apparently extracellular and 'extraneous' p62 positive particulate material in occasional high power fields.

\section{Results and discussion}

Trading on the 'tightly coupled' association between p62 pathological changes in the hippocampus and cerebellum and the possession of hexanucleotide repeat in C9ORF72 in FTLD [6-12], we sought to determine, from a pathological basis, whether such expansions might occur in patients with histopathologically verified $\mathrm{AD}$. Consequently, we screened 200 cases of AD for widespread TDP-43 pathological changes in hippocampus and temporal lobe, and for the presence of p62 positive NCI within

Table 1 Details of the 7 previous studies investigating the presence of a hexanucleotide expansion in C9ORF72 in patients with Alzheimer's disease

\begin{tabular}{lllll}
\hline Study & $\begin{array}{l}\text { Total number of } \\
\text { cases investigated } \\
\text { with clinical AD }\end{array}$ & $\begin{array}{l}\text { Number of cases } \\
\text { with expansion } \\
\text { in C9ORF72 }\end{array}$ & $\begin{array}{l}\text { Number of cases with expansion } \\
\text { in C9ORF72 with AD confirmed by } \\
\text { pathology (or on further clinical review) }\end{array}$ & $\begin{array}{l}\text { Number of cases with expansion in } \\
\text { C9ORF72 but with other disorders confirmed } \\
\text { by pathology (or on clinical review) }\end{array}$ \\
\hline$[14]$ & 904 & 11 & $0(0)$ & $0(11)$ \\
{$[15]$} & 1217 & 5 & $0(5)$ & $0(0)$ \\
{$[16]$} & 872 & 5 & $1(4)$ & $0(0)$ \\
{$[17]$} & 1184 & 11 & $3(6)$ & $1(1)$ \\
{$[18]$} & 342 & 6 & $0(5)$ & $1(0)$ \\
{$[19]$} & 568 & 0 & 0 & 0 \\
{$[20]$} & 424 & 0 & $0(0)$ & $0(0)$ \\
Total & 5511 & 38 & $4(20)$ & $2(12)$ \\
\hline
\end{tabular}


hippocampus (dentate gyrus, CA2/3/4 cells) and cerebellum (granule cells). Forty five (22.5\%) of the 200 cases of AD showed TDP-43 pathology mostly resembling FTLD-TDP type A histology [13], within the dentate gyrus granule cells and entorhinal cortex/fusiform gyrus, and within layer II pyramidal cells of inferior and middle temporal gyri (as described previously by us [22] and others $[21,23,24])$. However, no p62 immunoreactive NCI were seen within pyramidal cells of areas CA2/3/4, or within dentate gyrus granule cells, of the hippocampus [9], or within granule cells of the cerebellum [10], in any of these 45 cases, or in any of those cases of AD not showing TDP-43 pathology. Hence, we conclude that, even in the absence of formal genetic analysis, none of the 200 cases of $\mathrm{AD}$ examined here would likely be carriers of C9ORF72 expansion.

All previous studies have been based either, exclusively on cohorts of patients with clinically diagnosed $\mathrm{AD}$, or on cohorts with clinical $\mathrm{AD}$ but with limited pathological investigations in some expansion bearing, or non-bearing, individuals [14-20] (see Table 1). Collectively, these 7 studies have investigated 5511 patients with clinically diagnosed AD. A total of 38 patients were found to bear expansions in C9ORF72. Of these, of further clinical review, 24 were still considered to have $\mathrm{AD}$, and this was confirmed on pathology in 4 instances. Of the other 14 patients, 12 were considered to have FTLD on further review of the clinical notes, and two had this diagnosis confirmed on pathology. Hence, of all the 38 expansion carriers disclosed in these studies, only 4 could be said to have definite AD. Therefore, in the absence of pathological confirmation of disease, it remains possible that many of the remaining carriers of expansions in C9ORF72 with a clinical presentation compatible with AD could actually represent phenocopies of FTLD. Nonetheless, it does appear that there are still a few cases with an expansion in C9ORF72 where AD has indeed been confirmed pathologically either in the index patient, or within other members of the families involved [16,17].

However, it is noted that, in these latter studies [16,17], expansion bearing cases had not had a full histopathological work up, including p62 and TDP-43 immunohistochemistry, in order either to confirm the expansion pathologically, or to rule out coincident FTLD or other neurodegeneration. Moreover, in at least 2/4 such cases, onset of disease had occurred after 70 years of age [17], with both individuals bearing Apolipoprotein E \&4 allele, one being homozygous for this [17]. We have previously shown that the presence of Alzheimer-type pathology, which may be sufficient in some instances to meet pathological criteria for $\mathrm{AD}$, can occur in elderly cases of FTLD, especially those bearing Apolipoprotein E $\varepsilon 4$ allele [25], and particularly so within unaffected regions of the posterior hemisphere [26]. It is therefore possible that the occurrence of AD pathology in expansion bearers in the aforementioned studies $[16,17]$ is entirely coincidental, and unrelated to the expansion. Indeed, we have also shown that elderly subjects with FTLD commonly present with an AD-like syndrome [27]. Hence, it remains possible that in such individuals with AD pathology, the expansion in C9ORF72 might in fact may be responsible for directing an FTLD type of process, which has not be disclosed, since apparently in none of these studies had expansion carriers been investigated for these kinds of histological changes.

\section{Conclusions}

In conclusion, in the present study, we sought histological evidence for the presence of expansions in C9ORF72 among 200 patients with pathologically confirmed AD, but did not detect any cases where relevant tissue changes were present. We conclude that expansions in C9ORF72 are a rare occurrence in $\mathrm{AD}$, and in instances where these do occur, the presence of $\mathrm{AD}$ may be coincidental and unrelated to the expansion. Further investigations on such cases to exclude the presence of an underlying FTLD process driven by the expansion appear warranted.

\section{Competing interests}

The authors declare that they have no competing interests.

\section{Authors' contributions}

YD performed all immunohistochemistry. AR provided technical assistance. JS helped with clinical characterisation of patients; DM performed study design, data and slide analysis and wrote the paper. All authors read and approved the final manuscript.

\section{Acknowledgement}

We acknowledge the support of Alzheimers Research UK and Alzheimer's Society through their funding of the Manchester Brain Bank under the Brains for Dementia Research (BDR) initiative. DMAM receives funding from MRC and Wellcome Trust, which supported this study in part.

Received: 5 August 2013 Accepted: 10 August 2013

Published: 12 August 2013

\section{References}

1. Snowden JS, Thompson JC, Stopford CL, Richardson A, Gerhard A, Neary D, Mann DMA: The clinical diagnosis of early-onset dementias: diagnostic accuracy and clinicopathological relationships. Brain 2011, 134:2478-2492.

2. Baborie A, Griffiths TD, Jaros E, Richardson A, Ferrari R, Moreno J, Momeni P, McKeith IG, Burn DJ, Duplessis D, Pal P, Rollinson S, Pickering-Brown SM, Thompson JC, Neary D, Snowden JS, Perry R, Mann DMA: Pathological correlates of Frontotemporal Lobar Degeneration in the elderly. Acta Neuropathol 2011, 12:365-373.

3. Hutton M, Lendon CL, Rizzu P, Baker M, Froelich S, Houlden M, PickeringBrown SM, Chakraverty S, Isaacs A, Grover A, Hackett J, Adamson J, Lincoln S, Dickson D, Davies P, Petersen RC, Stevens M, De Graaf E, Wauters E, Van Baren J, Hillebrand M, Joosse M, Kwon JM, Nowotny P, Che LK, Norton J, Morris JC, Reed LA, Trojanowski JQ, Basun H, Lannfelt L, Neystat M, Fahn S, Dark F, Tannenberg T, Dodd P, Hayward N, Kwok JBJ, Schofield PR, Andreadis A, Snowden J, Craufurd D, Neary D, Owen F, Oostra BA, Hardy J, Goate A, Van Swieten J, Mann DM, Lynch T, Heutink P: Association of missense and $5^{\prime}$-splice-site mutation in tau with inherited dementia FTDP-17. Nature 1998, 393:702-705

4. Baker M, Mackenzie IRA, Pickering-Brown SM, Gass J, Rademakers R, Lindholm C, Snowden J, Adamson J, Sadovnick AD, Rollinson S, Cannon A, Dwosh E, Neary D, Melquist S, Richardson A, Dickson D, Eriksen J, Robinson T, Zehr C, Dickey CA, Crook R, McGowan E, Mann D, Boeve B, Feldman H, 
Hutton M: Mutations in Progranulin cause tau-negative frontotemporal dementia linked to chromosome 17. Nature 2006, 442:916-919.

5. Cruts M, Gijselinck I, Van der Zee J, Engelborghs S, Wils H, Pirici D, Rademakers R, Vandenberghe R, Dermaut B, Martin JJ, Van Duijn C, Peeters K, Sciot R, Santens P, De Pooter T, Mattheijssens M, Van den Broeck M, Cuijt I, Vennekens K, De Deyn PP, Kumar-Singh S, Van Broeckhoven C: Null mutations in progranulin cause ubiquitin-positive frontotemporal dementia linked to chromosome 17q21. Nature 2006, 442:920-924.

6. De Jesus-Hernandez M, Mackenzie IR, Boeve BF, Boxer AL, Baker M, Rutherford NJ, Nicholson AM, Finch NA, Flynn H, Adamson J, Kouri N, Wojtas A, Sengdy P, Hsiung GY, Karydas A, Seeley WW, Josephs KA, Coppola G, Geschwind DH, Wszolek ZK, Feldman H, Knopman DS, Petersen RC, Miller BL, Dickson DW, Boylan KB, Graff-Radford NR, Rademakers R: Expanded GGGGCC Hexanucleotide repeat in noncoding region of C9ORF72 causes chromosome 9p-linked FTD and ALS. Neuron 2011, 72:245-256.

7. Gijselinck I, Engelborghs S, Maes G, Cuijt I, Peeters K, Mattheijssens M, Joris G, Cras P, Martin JJ, De Deyn PP, Kumar-Singh S, Van Broeckhoven C, Cruts M: Identification of 2 Loci at chromosomes 9 and 14 in a multiplex family with frontotemporal lobar degeneration and amyotrophic lateral sclerosis. Arch Neurol 2010, 67:606-616.

8. Renton AE, Majounie E, Waite A, Simón-Sánchez J, Rollinson S, Gibbs JR, Laaksovirta H, Schymick JC, van Swieten J, Myllykangas L, Kalimo H, Paetau A, Abramzon Y, Remes AM, Kaganovich A, Scholz SW, Duckworth J, Ding J, Harmer DW, Hernandez DG, Johnson JO, Mok K, Ryten M, Trabzuni D, Guerreiro RJ, Orrell RW, Neal J, Murray A, Pearson J, Jansen IE, Sondervan D, Seelaar H, Blake D, Young K, Halliwell N, Callister J, Toulson G, Richardson A, Gerhard A, Snowden J, Mann D, Neary D, Nalls MA, Peuralinna T, Jansson L, Isoviita V-M, Kaivorinne A-L, Holtta-Vuori M, Ikonen E, Sulkava R, Benatar M, Wuu J, Chio A, Restagno G, Borghero G, Sabatelli M, The ITALSGEN Consortium, Heckerman D, Rogaeva E, Zinman L, Rothstein J, Sendtner M, Drepper C, Eichler EE, Alkan C, Abdullaev Z, Pack SD, Dutra A, Pak E, Hardy J, Singleton A, Williams NM, Heutink P, Pickering-Brown S, Morris HR, Tienari $P J$, Traynor BJ: A hexanucleotide repeat expansion in C9ORF72 is the cause of chromosome 9p21-linked amyotrophic lateral sclerosis-frontotemporal dementia. Neuron 2011, 72:257-268.

9. Al-Sarraj S, King A, Troakes C, Smith B, Maekawa S, Bodi I, Rogelj B, Al-Chalabi A, Hortobagyi T, Shaw CE: p62 positive, TDP-43 negative, neuronal cytoplasmic and intranuclear inclusions in the cerebellum and hippocampus define the pathology of C9orf72-linked FTLD and MNA/ALS. Acta Neuropathol 2011, 122:691-702.

10. Boxer AL, Mackenzie IR, Boeve BF, Baker M, Seeley WW, Crook R, Feldman H, Hsiung G-Y, Rutherford N, Laluz V, Whitwell J, Fote D, McDade E, Molano J, Karydas A, Wojtas A, Goldman J, Mirsky J, Sengdy P, DeArmond S, Miller BL, Rademakers R: Clinical, neuroimaging and neuropathological features of a new chromosome 9p-linked FTD-ALS family. J Neurol Neurosurg Psychiatry 2011, 82:196-203.

11. King A, Maekawa S, Bodi I, Troakes C, Al-Sarraj S: Ubiquitinated, p62 immunopositive cerebellar cortical neuronal inclusions are evident across the spectrum of TDP-43 proteinopathies but are only rarely additionally immunopositive for phosphorylation-dependent TDP-43. Neuropathology 2011, 31:239-249.

12. Snowden JS, Rollinson S, Thompson JC, Harris J, Stopford CL, Richardson A Jones M, Gerhard A, Davidson Y, Robinson A, Gibbons L, Hu Q, Halliwell N, DuPlessis D, Neary D, Mann DMA, Pickering-Brown S: Distinct clinical characteristics in patients with frontotemporal dementia and C9ORF72 mutations: a study of demographics, neurology, behaviour, cognition, and histopathology. Brain 2012, 135:693-708.

13. Mackenzie IRA, Neumann M, Baborie A, Sampathu DM, Du Plessis D, Jaros E, Perry RH, Trojanowski JQ, Mann DMA, Lee VM-Y: A harmonized classification system for FTLD-TDP pathology. Acta Neuropathol 2011, 122:111-113.

14. Beck J, Poulter M, Hensman D, Rohrer JD, Mahoney CJ, Adamson G, Campbell T, Uphill J, Borg A, Fratta P, Orrell RW, Malaspina A, Rowe J, Brown J, Hodges J, Sidle K, Polke JM, Houlden H, Schott JM, Fox NC, Rossor MN, Tabrizi SJ, Isaacs AM, Hardy J, Warren JD, Collinge J, Mead S: Large C9orf72 hexanucleotide repeat expansions are seen in multiple neurodegenerative syndromes and are more frequent than expected in the UK population. Am J Hum Genet 2013, 92:345-353.

15. Cacace R, Van Cauwenberghe C, Bettens K, Gijselinck I, Van der Zee J, Engelborghs S, Vandenbulcke M, Van Dongen J, Bäumer V, Dillen L, Mattheijssens M, Peeters K, Cruts M, Vandenberghe R, De Deyn PP, Van
Broeckhoven C, Sleegers K: C9orf72 G4C2 repeat expansions in Alzheimer's disease and mild cognitive impairment. Neurobiol Aging 2013, 34:1712.e1-7.

16. Harms M, Benitez BA, Cairns N, Cooper B, Cooper P, Mayo K, Carrell D, Faber K, Williamson J, Bird T, Diaz-Arrastia R, Foroud TM, Boeve BF, Graff-Radford NR, Mayeux R, Chakraverty S, Goate AM, Cruchaga C; NIA-LOAD/NCRAD Family Study Consortium: C9orf72 hexanucleotide repeat expansions in clinical Alzheimer disease. JAMA Neurol 2013, 70:736-741.

17. Kohli MA, John-Williams K, Rajbhandary R, Naj A, Whitehead P, Hamilton K, Carney RM, Wright C, Crocco E, Gwirtzman HE, Lang R, Beecham G, Martin ER, Gilbert J, Benatar M, Small GW, Mash D, Byrd G, Haines JL, Pericak-Vance MA, Züchner S: Repeat expansions in the C9ORF72 gene contribute to Alzheimer's disease in Caucasians. Neurobiol Aging 2013, 34:1519.e5-12.

18. Majounie E, Abramzon Y, Renton AE, Perry R, Bassett SS, Pletnikova O, Troncoso JC, Hardy J, Singleton AB, Traynor BJ: Repeat expansion in C9ORF72 in Alzheimer's disease. New Engl J Med 2013, 366:283-284.

19. Rollinson S, Halliwell N, Young K, Bennion Callister J, Toulson G, Gibbons L, Davidson Y, Robinson A, Gerhard A, Richardson A, Neary D, Snowden J, Mann D, Pickering Brown SM: Analysis of the hexanucleotide repeat in C9ORF72 in Alzheimer's disease. Neurobiol Aging 2012, 33:1846.e5-6.

20. Xi Z, Zinman L, Grinberg Y, Moreno D, Sato C, Bilbao JM, Ghani M, Hernández I, Ruiz A, Boada M, Morón FJ, Lang AE, Marras C, Bruni A, Colao R, Maletta RG, Puccio G, Rainero I, Pinessi L, Galimberti D, Morrison KE, Moorby C, Stockton JD, Masellis M, Black SE, Hazrati LN, Liang Y, Van Haersma de With J, Fornazzari L, Villagra R, Rojas-Garcia R, Clarimón J, Mayeux R, Robertson J, St George-Hyslop P, Rogaeva E: Investigation of c9orf72 in 4 neurodegenerative disorders. Arch Neurol 2012, 69:1583-1590.

21. Amador-Ortiz C, Lin W-L, Ahmed Z, Personett D, Davies P, Duara R, Graff-Radford NR, Hutton ML, Dickson DW: TDP-43 immunoreactivity in hippocampal sclerosis and Alzheimer's disease. Ann Neurol 2007, 61:435-445.

22. Davidson YS, Raby S, Foulds PG, Robinson A, Thompson JC, Sikkink S, Yusuf I, Amin H, DuPlessis D, Troakes C, Al-Sarraj S, Esiri MM, Prasher VP, Allsop D, Neary D, Pickering-Brown SM, Snowden JS, Mann DMA: TDP-43 pathological changes in early onset familial and sporadic Alzheimer's disease, late onset Alzheimer's disease and Down's Syndrome: association with age and clinical phenotype. Acta Neuropathol 2011, 122:703-713.

23. Hu WT, Josephs KA, Knopman DS, Boeve BF, Dickson DW, Petersen RC, Parisi JE: Temporal lobar predominance of TDP-43 neuronal cytoplasmic inclusions in Alzheimer's disease. Acta Neuropathol 2008, 116:215-220.

24. Uryu K, Nakashima-Yasuda H, Forman MS, Kwong LK, Clark CM, Grossman M, Miller BL, Kretzschmar HA, Lee VM-Y, Trojanowski JQ, Neumann M: Concomitant TAR-DNA-binding protein 43 pathology is present in Alzheimer disease and corticobasal degeneration but not in other tauopathies. J Neuropathol Exp Neurol 2008, 67:555-564.

25. Mann DMA, McDonagh AM, Pickering-Brown SM, Kowa H, Iwatsubo T: Amyloid $\beta$ protein deposition in patients with frontotemporal lobar degeneration: relationship to age and apolipoprotein $\mathrm{E}$ genotype. Neurosci Lett 2001, 304:161-164.

26. Mann DMA, Jones D, South PW, Snowden JS, Neary D: Deposition of amyloid $B$ protein in non-Alzheimer type dementias; evidence for a neuronal origin of parenchymal deposits of $\beta$ protein in neurodegenerative disease. Acta Neuropathol 1992, 83:415-419.

27. Baborie A, Griffiths TD, Jaros E, Momeni P, McKeith IG, Burn DJ, Mann DMA, Perry R: Frontotemporal dementia in elderly individuals. Arch Neurol 2012, 69:1052-1060.

doi:10.1186/2051-5960-1-50

Cite this article as: Davidson et al.: Pathological assessments for the presence of hexanucleotide repeat expansions in C9ORF72 in Alzheimer's disease. Acta Neuropathologica Communications 2013 1:50. 